\title{
Pengaruh Kegemaran Membaca terhadap Keterampilan Menulis Narasi
}

\author{
Eka Sariyanti Almana, Santa, Wawan Syahiril Anwar \\ Universitas Pakuan Bogor \\ ekasariyanitialmana357@gmail.com
}

\section{Sejarah Artikel \\ diterima 16/08/2019}

disetujui 28/08/2019

\begin{abstract}
The research aims to determine the positive effect on reading fondness with narrative writing skills. It is correlational research. The research subjects are students of class IV A and IV B of Tlajung Udik State Elementary School 01 Gunung Putri Sub-District, Bogor Regency consisting of 44 sample respondents. The results shows that there is an influence of reading fondness on narrative writing skills, indicated by statistical analysis that resulted in a correlation coefficient $\left(r_{x y}\right)$ of 0.93. This shows the influence of reading fondness on narrative writing skills, with the determination coefficient $\left(r^{2}\right)$ of 0.8649 or $86 \%$. This means that the reading fondness value of narrative writing skills is $86 \%$, through the regression equation $\hat{Y}=(59.6+0.74 X)$, and $14 \%$ is determined by other factors. It can be concludes that there is a positive and significant effect between reading fondness in narrative writing skills.

Keywords: reading, narrative writing skills
\end{abstract}

\begin{abstract}
Abstrak
Tujuan penelitian ini adalah untuk mengetahui pengaruh positif terhadap kegemaran membaca dengan keterampilan menulis narasi. Penelitian ini adalah penelitian korelasional. Subjek penelitian ini adalah siswa kelas IV A dan IV B Sekolah Dasar Negeri Tlajung Udik 01 Kecamatan Gunung Putri Kabupaten Bogor yang terdiri dari 44 sampel responden. Hasil penelitian menunjukkan bahwa terdapat pengaruh kegemaran membaca terhadap keterampilan menulis narasi, ditunjukkan dengan analisis statistik yang menghasilkan harga koefisien korelasi $\left(r_{\mathrm{xy}}\right)$ sebesar 0,93. Ini menunjukkan adanya pengaruh kegemaran membaca terhadap keterampilan menulis narasi, sedangkan koefisien determinasi $\left(r^{2}\right)$ sebesar 0.8649 atau sebesar $86 \%$. Hal ini berarti nilai kegemaran membaca terhadap keterampilan menulis narasi sebesar $86 \%$, melalui persamaan regresi $\hat{Y}=(59,6+0,74 X)$ sisanya $14 \%$ ditentukan oleh faktor lain. Berdasarkan hasil penelitian tersebut dapat disimpulkan bahwa terdapat pengaruh yang positif dan signifikan antara kegemaran membaca terhadap keterampilan menulis narasi.

Kata kunci : membaca, keterampilan menulis narasi
\end{abstract}

e-ISSN 2581-1835

p-ISSN 2581-1843

This work is licensed under a Creative Commons Attribution-ShareAlike 4.0 International License. 


\section{PENDAHULUAN}

Bahasa merupakan alat komunikasi yang dapat digunakan oleh individu untuk menyampaikan gagasan, pikiran dan perasaan, dalam kehidupan sehari-hari. Setiap individu dapat saling berinteraksi dan berkomunikasi antara satu sama lainnya degan menggunakan bahasa. Bahasa sebagai alat komunikasi yang dipakai oleh manusia baik dilakukan secara lisan dan tulisan. Komunikasi dengan lisan berarti seseorang secara langsung menyampaikan pesan kepada lawan bicaranya, sedangkan komunikasi tulisan secara tidak langsung menyampaikan pesan kepada lawan bicaranya, menggunakan media tulisan yang dapat dipertanggungjawabkan kepada orang lain.

Pembelajaran

Bahasa

Indonesia merupakan salah satu pembelajaran utama yang harus ada di setiap jenjang pendidikan, mulai dari Sekolah Dasar hingga Perguruan Tinggi. Pelajaran Bahasa Indonesia diajarkan berdasarkan kurikulum yang berlaku didalam pendidikan. Pentingnya tujuan utama pembelajaran Bahasa Indonesia di sekolah, agar siswa mampu menggunakan bahasa dengan baik dan benar. Untuk mencapai tujuan tersebut, maka siswa diwajibkan untuk berbahasa Indonesia. Empat komponen keterampilan yang harus dikuasai dalam Bahasa Indonesia yaitu keterampilan menyimak, keterampilan berbicara, keterampilan membaca dan keterampilan menulis.

Keterampilan

erat hubungannya dengan keempat keterampilan lainnya dengan cara yang beraneka ragam. Keterampilan menyimak adalah keterampilan yang paling mendasar, pada masa kecil kita belajar untuk menyimak bahasa. Kemudian keterampilan berbicara dapat dilakukan oleh semua orang dengan memiliki makna dan tujuan. Keterampilan membaca memperoleh berbagai pengetahuan keterampilan dari menyimak, berbicara, dan menulis. Membaca memiliki pengaruh terhadap menulis, jika seseorang gemar membaca akan tampak apabila mampu mengemukakan berbagai pengetahuan, gagasan, dan ide-ide kreatifnya salah satunya dalam penulisan. Namun, menulislah yang paling utama dikarenakan setiap orang mempunyai peranan penting dalam kehidupan. Keterampilan menulis tidak hanya diperlukan pada saat seseorang masih bersekolah bahkan, setelah lulus pun perlu memiliki keterampilan menulis.

Berdasarkan hasil observasi yang dilakukan oleh peneliti di Sekolah Dasar Negeri Tlajung Udik 01 siswa kelas IV menunjukan bahwa keterampilan menulis narasi pada siswa rendah sebanyak $40 \%$ dengan jumlah siswa sebanyak 78 siswa, dari kelas IV A sebanyak 41 siswa, sedangkan kelas IV B sebanyak 37 siswa. Hal ini dilihat dari hasil observasi dengan guru wali kelas IV A dan IV B dari beberapa siswa yang telah mampu mengungkapkan gagasannya dalam bentuk tulisan, tetapi kalimat yang disusunnya belum efektif. Terjadi pengulangan kalimat, penulisan ejaan banyak yang salah, serta kosakata atau pembendaharaan kata siswa masih belum bervariasi.

Proses menulis narasi siswa kelas IV sekolah dasar ini ditunjang dengan menanamkan kegemaran membaca. Siswa akan mampu menulis apabila mereka diberi tahu karya-karya penulis secara nyata. 
Menulis narasi dapat dilakukan dengan membiasakan membaca berbagai buku cerita maupun buku pembelajaran. Siswa dengan cara membaca buku, maka akan memperoleh pembendaharan kata atau suku kata lebih banyak, meningkatkan pengetahuan dan wawasan.

Kegemaran membaca berarti sebagai kesukaan akan membaca, terdapat kecendrungan hati ingin membaca. Proses dan kegiatan membaca harus memiliki makna atau tujuan. Penanaman gemar membaca untuk anak sangat penting bagi keberhasilan menulis. Kebanyakan anak perlu dukungan yang cukup besar untuk gemar membaca.

$$
\text { Banyak faktor yang }
$$

menyebabkan siswa masih rendah dalam membaca karena kurang gemar membaca, yang tidak terlepas dari kesadaran diri sendiri akan pentingnya membaca untuk meningkatan pengetahuan. Faktor lainnya banyak media elektronik yang mengundang hal negatif seperti televisi dan internet kebanyakan berisi tentang hiburan atau permainan dan hal-hal lainnya yang membuat kemalasan dari sifat kegemaran membaca. Sedangkan hal-hal yang tentang edukatif sedikit diperlihatkan. Untuk itu peran guru dapat mengelola berbagai kegiatan yang mampu menumbuhkan rasa kegemaran membaca.

Berdasarkan permasalahan diatas dapat diidentifikasikan masalah yang terkait dengan kegemaran membaca terhadap keterampilan menulis narasi yaitu siswa dalam penyusunan kalimat belum terampil, siswa kurang menanamkan kegemaran membaca buku cerita dan buku pelajaran, siswa kurang meningkatan keterampilan menulis narasi, siswa dalam minat membaca yang rendah dapat mempengaruhi peningkatan keterampilan menulis, penyebab siswa kurangnya gemar membaca, salah satunya tv dan internet.Sesuai dengan identifikasi masalah di atas, maka masalah dibatasi/difokuskan pada hal-hal yang berkaitan dengan keterampilan menulis narasi sebagai variabel terikat dan kegemaran membaca sebagai variabel bebas di kelas IV SDN Tlajung Udik 01 Kecamatan Gunung Putri Kabupaten Bogor Semester Genap Tahun Pelajaran 2018/2019.

Berdasarkan identifikasi dan pembatasan masalah tersebut, maka dapat dirumuskan masalah dalam penelitian ini adalah: "Apakah terdapat Pengaruh Kegemaran Membaca Terhadap Keterampilan Menulis Narasi Pada Peserta Didik Kelas IV SDN Tlajung Udik 01 Kecamatan Gunung Putri Kabupaten Bogor Semester Genap Tahun Pelajaran 2018/2019?

Dari beberapa masalah yang melatar belakanginya dari hasil observasi tersebut maka perlu dilakukan penelitian lebih lanjut mengenai kegemaran membaca terhadap keterampilan menulis narasi. Untuk membahas kegemaran membaca dan keterampilan menulis narasi alangkah baiknya mengetahui pengertiannya terlebih dahulu.

Menurut Tarigan (2014:1-3) keterampilan itu erat pula berhubungan dengan proses-proses yang mendasari bahasa. Bahasa seseorang mencerminkan pikirannya. Semakin terampil seseorang berbahasa, semakin cerah dan jelas pula jalan pikirannya. Keterampilan hanya dapat diperoleh dan dikuasi dengan jalan praktik dan banyak pelatihan. Melatih keterampilan berbahasa berarti pula melatih 
keterampilan berpikir. Keterampilan menulis merupakan suatu keterampilan berbahasa yang dipergunakan untuk berkomunikasi secara tidak langsung, tidak secara tatap muka dengan orang lain.

Sutarno (2008:1) menulis adalah sebuah aktivitas yang tidak berdiri sendiri. Kegiatan itu berkaitan erat dengan hal-hal lain, seperti penguasaan materi, pemahaman metode penulisan, pemanfaatan sumber referensi, penguasaan bahasa, dan penggunaan media yang tepat.

Dalman (2018:4) menulis adalah proses penyampaian pikiran, angan-angan, perasaan dalam bentuk lambang/tanda/tulisan yang bermakna. Dalam kegiatan menulis terdapat suatu kegiatan merangkai, menyusun, melukiskan suatu lambang/tanda/tulisan berupa kumpulan huruf yang membentuk kata, kumpulan kata membentuk kelompok kata atau kalimat, kumpulan kalimat membentuk paragraf dan kumpulan paragraf membentuk wacana/karangan yang utuh dan bermakna.

Nasir (2010:1) menulis memiliki dua pengertian yang berbeda. Pertama adalah menulis di lembaran kertas, catatan harian, buku tulis dan sebagainnya. Menulis pada pengertian kedua adalah menulis untuk orang banyak.

Jamaris (2014:155) menulis adalah alat yang digunakan dalam melakukan komunikasi dan mengekspresikan diri secara nonverbal. Oleh sebab itu, yang dimaksud dengan menulis adalah tulisan tangan, mengarang, dan mengeja.

Gustini,dkk (2016:21) tujuan menulis itu untuk menginformasikan perjanjian atau janji. Untuk membujuk seseorang atau menjual sesuatu. Untuk memberikan informasi atau menjawab pertanyaan. Untuk meminta informasi atau tindakan. Untuk meminta informasi atau tindakan. Untuk membenarkan sesuatu. Untuk melaporkan kemajuan. Untuk meminta maaf. Untuk menawarkan simpati.

$$
\text { Suparno dan Yunus }
$$

(2006:1.17) tujuannya menulis adalah menunjukkan atau menginformasikan kepada pembaca mengenai dampak negatif tayangan terhadap televisi terhadap perilaku anak-anak. Tujuan menulis akan mempengaruhi (genre) dan bentuk karangan, gaya penyampaiannya, serta tingkat kerincian isi karangan.

Dalman (2018:106) karangan narasi adalah karangan yang berusaha menciptakan, mengisahkan, dan merangkaikan tindak-tanduk manusia dalam sebuah peristiwa manusia dari waktu ke waktu, juga didalamnya terdapat tokoh yang menghadapi suatu konflik yang disusun secara sistematis.

Abigail (2015:18) Narasi adalah tulisan yang berupa rangkaian peristiwa yang terjadi dalam satu kesatuan waktu. Narasi sering diartikan juga cerita. Cerita merupakan penulisan yang mempunyai karakter, setting, waktu, dan masalah. Karangan yang tergolong jenis narasi yatu cerpen, novel, roman, atau semua karya prosa imajinatif. Narasi ditulis berdasarkan rekaan atau imajinasi. Namun narasi bisa ditulis berdasarkan pengalaman pribadi, pengamatan, atau wawancara. Sumber paling mudah digali untuk cerita adalah pengalaman pribadi. Kita tinggal menggali kenangan lama dan mengingat-ingat peristiwa yang pernah kita alami. Dalam tulisan narasi selalu ada tokohtokoh yang terlibat dalam peristiwa. 
Susanto (2013:251) menulis merupakan salah satu bagian terpenting dalam kehidupan seharihari. Sehingga tidak diragukan lagi, pengajaran menulis harus benarbenar diperhatikan dalam kegiatan pembelajaran bahasa Indonesia di sekolah. Bagaimana guru bisa memfasilitasi siswanya dan mampu menerapakan metode-metode inovatif yang kemudian mampu membuat siswa-siswanya pandai dalam hal tulis-menulis hingga mengolah kata dan pada akhirnya mampu menjadi seorang penulis yang handal, penulis yang ulung.

Keraf (2007:145-148) narasi merupakan cerita yang memiliki sebuah alur atau plot. Narasi dapat berisi fakta atau rekaan. Sebuah alur mengandung rangkaian peristiwa yang dapat membentuk suatu konflik dan klimaks yang dialami oleh para tokohnya pada suatu tempat dan waktu akhir narasi masi menimbulkan persoalan baru lagi. Perlu pembatasan rangkaian tindakan yang lebih jelas, yaitu rangkaian tindakan yang terdiri atas tahap-tahap yang penting dalam sebuah struktur yang diikat oleh waktu.

Jiwandono (2012:1) karangan narasi terdiri dari unsur-unsur instrinsik atau unsur-unsur yang membangun karangan narasi dari dalam. Unsur-unsur tersebut meliputi urutan peristiwa, latar, pelaku, perwatakan, tema , dan sudut pandang.

Berdasarkan teori-teori di atas
dapat disintesiskan bahwa
keterampilan menulis naras
merupakan kegiatan seseorang untuk menuangkan ide dan gagasan dalam bentuk kata, kalimat, dan paragraf yang secara tersusun bentuk tulisan narasi yang berusaha untuk menciptakan, mengisahkan dan merangkai suatu kejadian atau peristiwa, dan alur kronologis sehingga dapat dipahami oleh pembaca adapun unsur-unsur karangan narasi yaitu alur atau plot, penokohan (tokoh), latar (waktu dan tempat), dan tema.

Hanifah (2012:3) di dalam jurnalnyakegemaran membaca merupakan aktivitas yang menunjukan kesukaan dan kesenangan seseorang terhadap proses pengolahan informasi yang terdapat dalam cerpen melalui berbagai keterampilan, seperti pemahaman, pengamatan, penilaian sehingga dihasilkan suatu kesimpulan.

Zulamri (2013:76) gemar membaca dapat diartikan sebagai rasa tertarik, munculnya rasa perhatian atau rasa senangnya seseorang untuk melakukan kegiatan membaca. Kegemaran berarti sesuatu yang sudah melekat, yang menjadi kebiasaan seseorang karena sudah menjadi kesenangan individu dalam menjalaninya secara terus menerus. Sehingga orang yang memiliki kegemaran membaca otomatis dia memiliki kebiasaan yang lazim dijalaninya sejak dia masih kecil.

Humaeroh

(2015:19) kegemaran membaca merupakan salah satu kunci keberhasilan seseorang dalam meraih ilmu pengetahuan dan teknologi. Untuk itu guru perlu mengelola berbagai kegiatan yang mampu menumbuhkan kegemaran membaca.

Nurhadi

(2004:134)

menyatakan bahwa tujuan membaca dianggap sebagai modal dalam membaca. Menelusuri baris-baris bacaan (membaca) dapat mempengaruhi hasil membacannya.

Rahim (2011:13) peningkatan kemampuan berpikir melalui membaca seharusnya dimulai sejak 
dini. Guru SD dapat membimbing siswanya dengan memberikan pertanyaan-pertanyaan yang memungkinkan mereka bisa meningkatkan kemampuan berpikirnya. Pertanyaan-pertanyaan yang diajukan guru hendaknya merangsang siswa berpikir, seperti pertanyaan mengapa dan bagaimana.

Daryanto (2015:267) Peminat buku bacaan itu berbagai macam tingkatan usia dan berbeda jenis kelaminnya, dari segi usia, mulai dari anak-anak, remaja, pemuda, maupun orangtua. Kemampuan membaca setiap rang berbeda. Lama tidaknya seseorang belajar/membaca dipengaruhi oleh kedewasaan. Minat biasanya mempunyai andil yang cukup besar dalam kegiatan membaca seseorang. Namun, minat tidak bisa dijadikan sebagai faktor penentu baik atau buruknya membaca seseorang dalam belajar.

Somadoyo (2011:30-31) bahwa ada Sembilan faktor yang mempengaruhi kegiatan membaca. Sembilan faktor tersebut adalah tingkat intelegensi, kemampuan berbahasa, sikap dan minat, kebiasaan membaca, pengetahuan tentang cara membaca, latar belakang sosial, ekonomi dan budaya,keadaan emosi, pengetahuan dan pengalaman yang dimiliki sebelumnya.
Asri (2016:138) buku bacaan informasi untuk anak-anak, dan ada banyak alasan untuk memasukkan ke dalam kurikulum sekolah dasar. Berbagai buku informasi untuk anakanak dapat menggabungkan tulisantulisan informasi ini ke perpustakaan dan di kelas-kelas. Dengan demikian, untuk mengatur strategi pemilihan ragam buku anak harus memiliki alur cerita yang bermoral atau mengandung pesan yang penting.

Berdasarkan kajian teoritik diatas, maka disintesiskan bahwa kegemaran membaca berarti sebagai kesukaan akan membaca, terdapat kecendrungan hati ingin membaca penanaman gemar membaca untuk anak sangat penting bagi keberhasilan menulis kegemaran membaca seseorang mempunyai tujuan untuk mendapatkan informasi terhadap isi teks yang dibaca dan dapat memahami makna atau arti yang terkandung didalam teks bacaan faktor-faktor yang mempengaruhi kegemaran membaca yaitu faktor fisiologis, faktor intelektual, faktor lingkungan, faktor psikologis memilih bahan bacaan yang dipilih guru seperti buku teks, buku sastra anakanak, majalah anak-anak, surat kabar, buku referensi.

\section{METODE}

Penelitian dilaksanakan pada siswa kelas IV Sekolah Dasar Negeri Tlajung Udik 01 Kecamatan Gunung Putri Kabupaten Bogor, semester genap tahun pelajaran 2018/2019 pada bulan April 2019. Metode penelitian yang digunakan adalah metode kuantitatif studi kausal.

Populasi dalam penelitian adalah seluruh siswa kelas IV di
Sekolah Dasar Negeri Tlajung Udik 01 Kecamatan Gunung Putri Kabupaten Bogor dengan jumlah populasi sebanyak 78 siswa. Teknik pengambilan sampel menggunakan simple random sampling .yaitu dengan menggunakan sistem acak tanpa memperhatikan strata. Banyak sampel di Sekolah Dasar Negeri Tlajung Udik 01 Kecamatan Gunung Putri 
Kabupaten Bogorsebagai tempat penelitian dihitung dengan menggunakan rumus Taro Yamane dengan menggunakan presisi 10\% sehingga mendapatkan sampel sebanyak 44 siswa dengan masingmasing 23 siswa kelas IV A dan 21 siswa kelas IV B.

Teknik pengumpulan data merupakan teknik atau cara yang digunakan oleh penulis untuk memperoleh data yang tepat kemudian dilanjutkan dengan menyusun alat pembentuknya yang disebut degan instrumen. Teknik pengumpulan data dengan menggunakan observasi, angket, tes. Angket (variabel kegemaran membaca) yang berisikan pernyataan-pernyataan yang menggunakan skala Likert yang terdiri dari lima rentang skor, adapun indikatornya yaitu mampu melaksanakan membaca secara fokus, mampu menggunakan waktu yang efektif, mampu mengutamakan membaca dari pekerjaan lain, mempu memberikan tanggapan terhadap buku yang dibaca, mampu memiliki, membeli, atau meminjam buku bacaan. Sedangkan tes (keterampilan menulis narasi) yang berupa soal tentang membuat tulisan narasi tema liburan sekolah, adapun aspek yang di nilai yaitu tokoh, latar, ide gagasan, penulisan ejaan (tata tulis), dan alur.

Teknik analisis data yang digunakan yaitu 1) analisis data deskriptif diantaranya mean, range, banyak kelas, interval kelas, median, modus, varians sampel, dan standar deviasi, 2) uji prasyarat analisis yaitu a) uji normalitas yang digunakan adalah uji Liliefors, b) uji homogenitas yang digunakan adalah uji Fisher, c) uji signifikasi, lalu uji korelasi dan uji determinasi. Pembaruan dari penelitian ini untuk menanamkan kegemaran membaca, siswa mampu menulis apabila mereka diberitahu karya-karya penulis secara nyata. Menulis narasi dapat dilakukan dengan membiasakan membaca berbagai buku cerita maupun buku pelajaran. Siswa dengan cara membaca buku, maka akan memperoleh pembendaharaan kata atau suku kata lebih banyak, untuk meningkatkan pengetahuan dan wawasan.

\section{PEMBAHASAN}

\begin{abstract}
Variabel Keterampilan Menulis
Narasi (Y). Berdasarkan hasil perhitungan variabel Keterampilan Menulis Narasiberupa tes membuat karangan narasi tentang liburan yang diisi oleh44 responden siswa, total skor dari karakter siswa yaitu 3110 , Rata-rata (mean) 70,68, Nilai tengah (median) 57, Nilai yang sering muncul (modus) 59, Banyak kelas6, Jarak
\end{abstract}

kelas 7, Varians sampel 115,06, Standar deviasi 10,723, Skor minimum 54, Skor maksimum 93, Jumlah responden 44, Rentang skor (range) 39. Adapun distribusi frekuensi data hasil penelitian variabel keterampilan menulis narasi dapat dilihat pada tabel di bawah ini: 


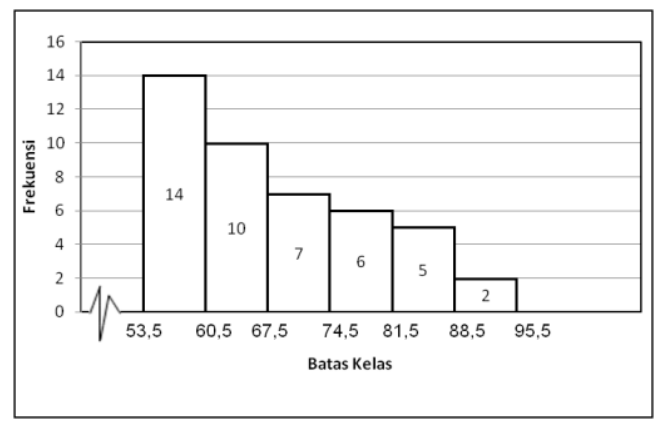

\section{Gambar 4.1. Diagram Histogram Data Hasil Penelitian Keterampilan Menulis Narasi $(Y)$}

a. Variabel Kegemaran Membaca (X). Berdasarkan dari perhitungan variabel kegemaran membaca yang terdiri dari 36butir pernyataan yang diisi oleh 44responden, maka didapat hasil sebagai berikut: jumlah total skor kegiatan pramuka adalah 3032,nilai mean 68,91, median 82, modus 82 , rentang skor 48 , standar deviasi 13,411 , nilai maksimum 88, nilai minimum 40 , varians sampel 179,85. Adapun distribusi frekuensi data hasil penelitian variabel kegemaran membaca dapat dilihat pada tabel di bawah ini:

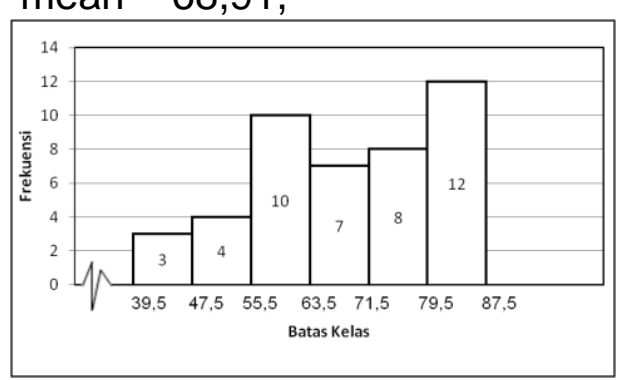

\section{Gambar 4.2 Diagram Histogram Data Hasil Penelitian Kegemaran Membaca (X)}

Uji Normalitas digunakan untuk variabel kegemaran membaca $(X)$ dan mengetahui data penelitian distribusi keterampilan menulis narasi (Y) normal atau tidaknya. Untuk dengan syarat:

mengujiny'a yaitu dengan $\mathrm{H}_{0}=L_{\text {hitung }}<L_{\text {tabel }}$, berarti galat baku menggunakan uji Liliefors untuk taksiran normal.

Tabel 1 Rangkuman Uji Normalitas Variabel $X$ dan Variabel $Y$

\begin{tabular}{ccccc}
\hline $\mathrm{N}$ & $\begin{array}{c}\text { Galat } \\
\text { Baku } \\
0\end{array}$ & $L_{\text {hitung }}$ & $L_{\text {tabel }}$ & Kesimpulan \\
\hline Taksiran & & & \\
\hline 1 & $\begin{array}{l}\text { Variabel } \\
\text { X dan Y }\end{array}$ & 0,07853 & $\begin{array}{c}0,133 \\
6\end{array}$ & Normal
\end{tabular}

Syarat Normal $L_{\text {hitung }}<L_{\text {tabel }}$

Berdasarkan uji normalitas tersebut dibandingkan dengan harga dengan menggunakan Liliefors Ltabel $=0,1336$ dan taraf kesalahan diperoleh Lhitung $=0,07853$. Harga $5 \%$, karena harga Lhitung lebih kecil 
dari harga Ltabel maka distribusi $\operatorname{membaca}(\mathrm{X})$
Keterampilan Menulis Narasi

tersebut normal. data kegemaran atas variabel

Tabel 2 Rangkuman Uji Homogenitas Variabel $X$ dan $Y$

\begin{tabular}{cccccc}
\hline No & $\begin{array}{c}\text { Varian } \\
\text { yang diuji }\end{array}$ & $\begin{array}{c}\text { Jumlah } \\
\text { Sampel }\end{array}$ & $\begin{array}{c}F_{\text {hitun }} \\
\mathrm{g}\end{array}$ & $\begin{array}{c}\mathrm{F}_{\text {tab }} \\
\text { el }\end{array}$ & $\alpha(0,05)$ \\
\hline 1 & $\mathrm{X}$ atas $\mathrm{Y}$ & 44 & $\begin{array}{c}1,56 \\
31\end{array}$ & $\begin{array}{c}4,0 \\
7\end{array}$ & $\begin{array}{c}\text { Homoge } \\
\mathrm{n}\end{array}$
\end{tabular}

Uji taraf signifikan $\mathrm{F}_{\text {hitung }}<\mathrm{F}_{\text {tabel }}$

\begin{abstract}
Berdasarkan hasil perhitungan menulis narasi memiliki varian yang homogenitas data kegemaran membaca dan keterampilan menulis narasi diperoleh nilai Fhitung $=1,5631$ sedangkan Ftabel $=4,07$ berdasarkan kriteria pengujian data di atas $\mathrm{Ho}$ diterima dan $\mathrm{H} 1$ ditolak, hal ini berarti skor pada variabel kegemaran membaca dan skor pada keterampilan sama.

Pengaruh antara variabel Kegemaran Membaca (X) dengan Keterampilan Menulis Narasi $(Y)$ yang berdasarkan hasil perhitungan uji signifikansi dan dinyatakan dalam bentuk persamaan regresi yaitu, $\dot{Y}=a$ + bX dapat dilihat pada diagram pencar berikut:
\end{abstract}

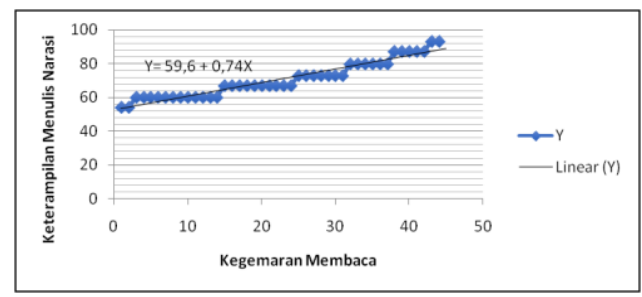

\title{
Gambar 4 Diagram Pencar Pengaruh Variabel Kegemaran Membaca (X)
} terhadap Keterampilan Menulis Narasi $(Y)$

Berdasarkan dengan hasil perhitungan analisis persamaan regresi pada gambar diagram pencar di atas menunjukkan suatu korelasi bahwa terdapat pengaruh positif dan menunjukkan keeratan antara kedua variabel dengan ketentuan korelasi positif variabel $Y$ akan naik jika variabel $X$ naik, jika variabel $X$ dikendalikan maka variabel $Y$ juga akan dikendalikan. Kebenaran dari hasil regresi di atas digunakan untuk menguji hipotesis mengenai ada tidaknya pengaruh positif terhadapKegemaran Membaca (X) dengan Keterampilan Menulis Narasi $(Y)$.Pengaruh fungsional antara $X$ dan $Y$ disajikan dalam bentuk $\hat{Y}=(59,6+$ $0,74 X$ ) dengan $X$ adalah signifikan.

Berdasarkan Perhitungan uji signifikan regresi diperoleh nilai Fhitung = $-0,498$ dengan Ftabel $(0,05)=2,33$ dan Ftabel $(0,01)$ $=3,38$ dengan dkpembilang $(k-2)=28$ dan dkpenyebut $(n-k)=14$. Dengan demikian Fhitung < Ftabel $(\alpha=0,05)<$ Ftabel $(\alpha=0,01)=-0,498<2,33<$ 3,38 . Sehingga dapat dinyatakan bahwa Fhitung < Ftabel berarti hipotesisi linear diterima, sehingga dapat disimpulkan antara data 
Keterampilan menulis narasi $(Y)$ dan Kegemaran membaca $(X)$ memiliki pola hubungan yang linear.

Berdasarkan nilai koefisien korelasi $r=0,93$ terdapat pada interval koefisien 0,800-1,000 yang berarti tingkat pengaruh antara dua variabel penelitian sangat kuat.

Nilai koefisien determinasi $\left(r^{2}\right)$ antara keterampilan menulis narasi ( $\mathrm{Y}$ ) adalah $r^{2}=0,8649$ dengan koefisien determinasi $86 \%$. Hal ini berarti bahwa kegemaran membaca memberi konstribusi sebesar $86 \%$ terhadap keterampilan menulis narasi, sedangkan $14 \%$ keterampilan menulis narasi dipengaruhi oleh faktor-faktor lain. kegemaran membaca $(X)$ dengan

\begin{tabular}{cccccc}
\multicolumn{2}{c}{ Tabel 4 Hasil Pehitungan Uji Signifikansi Korelasi Variabel $\mathbf{X}$ dan $\mathbf{Y}$} \\
$\begin{array}{c}\text { Koefisien } \\
\text { Korelasi }\end{array}$ & Dk & $T_{\text {hitung }}$ & $(\alpha 0,05)$ & $(\alpha 0,01)$ & Kesimpulan \\
\hline 0,93 & 42 & 16,398 & 2,018 & 2,698 & $\begin{array}{c}\text { Hubungan } \\
\text { positif } \\
\text { signifikan }\end{array}$ \\
\hline
\end{tabular}

Syarat Taraf Uji Signifikasi $=t_{\text {hitung }}>t_{\text {tabel }}$

Berdasarkan tabel di atas tentang hasil perhitungan uji signifikansi korelasi, diperoleh thitung sebesar 16,398 dengan derajat kebebasan 42, maka diperoleh thitung $>$ ttabel $(\alpha=$ $0,05)>$ ttabel $(\alpha=0,01)=16,398>$ $2,018>2,698$ sehingga daerah $\mathrm{H} 0$ berada pada interval $-2,018$ sampai 2,018 .

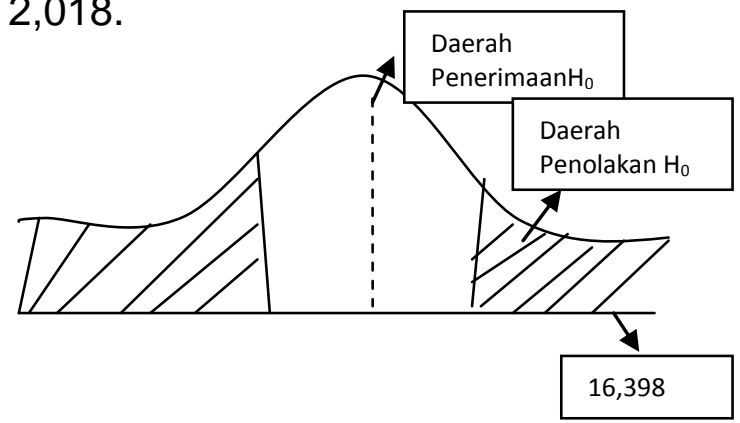

\section{Gambar 5 Kurva Penolakan dan Penerimaan $\mathrm{H}_{\mathrm{o}}$}

Berdasarkan hasil penelitian yang telah dilakukan bahwa kegemaran membaca memberikan pengaruh positif terhadap keterampilan menulis narasi. Hal ini semakin meningkatnya partisipasi dalam kegemaran membaca maka semakin terampil dalam menulis narasi.

Kegemaran membaca memiliki pengaruh yang sangat kuat terhadap keterampilan menulis narasi. Hasil yang ditemukan sekitar 86 persen bahwa perkembangan kenaikan dan penurunan siswa dalam keterampilan menulis narasi dapat dipengaruhi oleh kegemaran membaca, sedangkan 14 persen dari keterampilan menulis narasi dapat dipengaruhi oleh faktorfaktor lain. Susanti (2008: ii) mengungkapkan bahwa pengaruh kegemaran membaca terhadap kemampuan menulis lebih besar daripada pengaruh kegemaran menulis terhadap keterampilan menulis.

Pentingnya seseorang agar memiliki kegemaran membaca, Karena dengan membaca seseorang akan memperoleh informasi baru, pengetahuan yang cukup, wawasan yang luas, dan memiliki kecerdasan yang memadai, sehingga lebih mampu menjawab tantangan kehidupan di masa yang akan datang. Tarigan (2015:9) mengungkapkan 
bahwa "tujuan membaca adalah untuk mencari serta memperoleh informasi, mencakup isi, memahami makna bacaan."

Keinginan atau kegemaran membaca perlu dipaksakan, Karena tidak orang gemar untuk membaca. Ada beberapa factor yang dapat mempengaruhi seseorang gemar untuk membaca, menurut Rahadian (2014:32) "menerangkan bahwa timbulnya selera membaca disebabkan oleh adanya koleksi yang beragam dan variatif. Selanjutnya selera membaca ini akan menimbulkan minat baca, yang kalau di ulang terus-menerus dan menghasilkan kebiasaan membaca. Kebiasaan membaca ini akan menjadi landasan dari pengembangan koleksi. Faktor utama untuk menumbuhkan minat baca adalah koleksi.

Factor lain yang dapat mempengaruhi gemar membaca dilihat dari usia dan jenis kelamin, hal ini sesuai dengan pendapat Daryanto (2015:267) yang memngungkapkan bahwa "Peminat buku bacaan itu berbagai macam tingkatan usia dan berbeda jenis kelaminnya, dari segi usia, mulai dari anak-anak, remaja, pemuda, maupun orangtua. Kemampuan membaca setiap orang berbeda. Lama tidaknya seseorang belajar/membaca dipengaruhi oleh kedewasaan. Minat biasanya mempunyai andil yang cukup besar dalam kegiatan membaca seseorang. Namun, minat tidak bisa dijadikan sebagai faktor penentu baik atau buruknya membaca seseorang dalam belajar."

Kegemaran membaca seorang anak harus diperhatikan, agar dalam memilih bahan bacaan sesuai dengan tingkatan umur. Membelajarakan, mengajarkan dan mengajar untuk gemar membaca sejak dini terutama sejak SD merupakan hal yang tepat, apalagi ditingkat sekolah terdapat kurikulum yang mengharuskan anak untuk bisa membaca. mengajarkan kegemaran membaca sejak sekolah agar anak memperoleh informasi pengetahuan yang banyak dan luas. Asri (2016:138) mengungkapkan bahwa "buku bacaan informasi untuk anak-anak, dan ada banyak alasan untuk memasukkan ke dalam kurikulum sekolah dasar. Berbagai buku informasi untuk anak-anak dapat menggabungkan tulisan-tulisan informasi ini ke perpustakaan dan di kelas-kelas."

Kegemaran membaca merupakan perilaku atau kegiatan yang harus dibiasakan dan dimiliki oleh setiap individu. Membaca merupakan salah satu gerbang informasi untuk mendapatkan ilmu pengetahuan. dengan memiliki ilmu dan pengetahuan maka akan muncul ide, kreatifitas yang bisa dituangkan dalam bentuk tulisan-tulisan yang bermanfaat dan menginspirasi.

Kegiatan dalam menuangkan ide melalui pengalaman dengan tulisan di SD perlu dibiasakan dan dilatih sejak dini, sehingga kreatifitas anak bisa tersalurkan dengan baik. Membuat karangan adalah salah satu cara untuk menyalurkan ide yang dialami dan dirasakan. Salah satu karangan yang bisa dikembangkan di SD untuk menuangkan ide dari yang pernah dialami dalam suatu peristiwa yaitu karangan narasi. Finoza (2013:261) mengungkapka bahwa "Karangan narasi adalah suatu bentuk tulisan yang berusaha menciptakan, mengisahkan, merangkaikan tindaktanduk perbuatan manusia dalam sebuah peristiwa secara kronologis atau yang berlangsung dalam satu kesatuan waktu. Dari segi sifatnya karangan narasi dapat dibedakan atas 
dua macam yaitu narasi ekspositoris atau narasi faktual yaitu narasi yang bertujuan untuk memberikan informasi agar pengetahuannya bertambah dan sedangkan narasi sugestif atau narasi berplot yaitu narasi yang mampu menyampaikan makna kepada pembaca melalui daya khayal".

Menurut Jiwandono (2012:1) "karangan narasi terdiri dari unsurunsur instrinsik atau unsur-unsur yang membangun karangan narasi dari dalam. Unsur-unsur tersebut meliputi urutan peristiwa, latar, pelaku, perwatakan, tema , dan sudut pandang."

Keterampilan menulis narasi membutuhkan bahan/materi tulisan dan membutuhkan penguasaan perbendaharaan kata yang banyak sehingga memudahkan bagi penulis untuk menyampaikan apa yang dipikirkannya. Untuk menuangkan ide dan gagasan dalam bentuk kata, kalimat, dan paragraf yang secara tersusun, harus memiliki bentuk tulisan narasi yang berusaha untuk menciptakan, mengisahkan dan merangkai suatu kejadian atau peristiwa, dan alur kronologis sehingga dapat dipahami oleh pembaca.

Melalui kegemaran membaca dan siswa terbiasa untuk membaca maka makan akan menambah pengetahuan, pengalaman, dan wawasan, sehingga secara otomatis akan memiliki ide dan gagasan dalam bentuk kata, kalimat, dan paragraf yang secara sistematis dan tersusun dalam membuat karangan narasi yang baik dan berkualitas.

\section{SIMPULAN}

Berdasarkan hasil penelitian, ini diharapkan dapat menambah dan memperluas bagi pengembang ilmu kependidikan, terutama yang berkaitan dengan kegemaran membaca terhadap keterampilan menulis. Hasil penelitian ini didapatkan untuk memberi informasi bagi pihak sekolah dalam meningkatkan mutu pendidikan yang berhubungan dengan kegemaran membaca terhadap keterampilan menulis narasi. Penelitian ini diharapkan untuk menambah perbendaharaan kata atau kalimat dalam dunia pendidikan, khusunya dalam karya tulis ilmiah. Sehingga guru dan pihak sekolah terus memberikan motivasi, melatih dan membiasakan serta melengkapi fasilitas agar para siswanya memiliki kegemaran membaca untuk memliki keterampilan dalam menulis khususnya membuat karangan narasi

\section{DAFTAR PUSTAKA}

Asri, Tri Mega. 2016. "Buku Informasional untuk Anak-anak (Informational Books for Children)". e-ISSN 2442-5168 Program Pendidikan Vokasi Universitas Brawijaya. Vol 2 No 2.

Dalman, H. 2018. Keterampilan Menulis. Depok: PT. Raja Grafindo Persada.
Daryanto. 2015. Inovasi Pembelajaran Efektif. Bandung: Yrama Widya.

Gorys, Keraf. 2007. Argumentasi dan Narasi. Jakarta: PT. Gramedia Pustaka Utama.

Gustini, Neng.,Rohaniawati, Dede.,Imani, Anugrah. 2016. Budaya Literasi (Model Pengembangan Budaya Baca 
Tulis Berbasis Kecerdasan Majemuk Melalui Tutor Sebaya). Yogyakarta: Deepublish.

Hanifah, Ifah. 2012. "Korelasi Kegemaran Membaca Cerpen Dengan Kemampuan Menulis Cerpen Siswa Kelas Xi Sma Negeri 3 Kuningan". Universitas Kuningan.

Jamaris, Martini. 2014. Kesulitan Belajar Perspektif, Asesmen, dan Penanggulangannya. Bogor: Ghalia Indonesia.

Jiwandono, Robid Nahnu. 2012. "Karakteristik Karangan Narasi Siswa Kelas VII SMPN 6 Malang". Universitas Negeri Malang.

Nasir, Zulhasril. 2010. Menulis Untuk dibaca. Jakarta: Yayasan Pustaka Obor Indonesia

Nurhadi. 2004. Membaca Cepat dan Efektif. Bandung: Sinar Baru.
Rahim, Farida. 2011. Pengajaran Membaca di Sekolah Dasar. Jakarta: Bumi Aksara.

Somadoyo, Samsu. 2011. "Strategi dan Teknik Pembelajaran Membaca". Jakarta: PT. Gramedia Pustaka IImu.

Suparno dan Yunus. 2006. Keterampilan Dasar Menulis. Jakarta: Universitas Terbuka.

Susanto, Ahmad. 2013. Teori Belajar dan Pembelajaran di Sekolah Dasar. Jakarta: KENCANA.

Sutarno. 2008. Menulis yang Efektif. Jakarta: Sagung Seto

Tarigan, Henry Guntur. 2014. Menulis Sebagai Keterampilan Berbahasa. Bandung: Angkasa Bandung.

W, Abigail, Monica. 2015. Belajar Menulis. Surabaya: JP BOOKS.

Zulamri. 2013. "Hubungan Tingkat Kematangan Beragama Remaja Muslim Dengan Kegemaran Membaca". UIN Suska Riau 